\title{
Son sınıf fen bilgisi öğretmen adaylarının potansiyel fark konusundaki kavram yanılgıları
}

\author{
Mustafa Sabri KOCAKÜLAH ${ }^{1}$, Bengisu ABACI ${ }^{2, *}$ \\ ${ }^{I}$ Balıkesir Üniversitesi, Necatibey Eğitim Fakültesi, Fen Bilgisi Eğitimi Anabilim Dall, Balıkesir \\ ${ }^{2}$ Balıkesir Üniversitesi, Fen Bilimleri Enstitüsü, Matematik ve Fen Bilimleri Eğitimi Anabilim Dall, Balıkesir \\ Geliș Tarihi (Recived Date): 23.08 .2017 \\ Kabul Tarihi (Accepted Date): 06.12.2017
}

\begin{abstract}
Özet
Bu çalıșma Fen Bilgisi Öğretmenliği son sını öğrencilerinin "Elektrik Devreleri” konusundaki kavram yanılgılarını belirlemek amacıyla yapılmıştır. Kavramlardan "potansiyel fark" kavramı araştırılmıştır. Çalışmada 2006-2017 yıllarında uygulanmış olan kavram yanılgısı testi analiz edilmiştir. Bu amacı gerçekleş̧tirebilmek için 8 soruluk açıklamal-çoktan seçmeli test hazırlanmışstır. Bu sorulardan potansiyel fark ile ilgili kavram yanılgısını ölçen beşinci soru seçilip a ve $b$ şıklı soruları analiz edilmiştir. Sorular Balıkesir Üniversitesi Fen Bilgisi Öğretmenliğinde ögrrenim görmü̈s 399 ögrrenciye uygulanmıștır. Verilerin analizi sonucunda öğrencilerin çoğunlukla kavram yanılgısına sahip olduğu ve bu kavram yanılgılarının benzer olduğu belirlenmiştir.
\end{abstract}

Anahtar kelimeler: Elektrik, kavram yanılgısı, potansiyel fark, ögretmen adayları.

\section{Last year science teacher candidates' misconceptions about the potential difference}

\begin{abstract}
This study was conducted to determine the misconceptions about the "Electrical Circuits" of last year students of Science Teacher Education. The concept of "potential difference" has been explored. The misconceptions test, which was applied between the years 2006 and 2017, was analyzed. In order to achieve the aim of the study, a misconception test with 8 open ended-multiple-choice questions was prepared. The fifth question measuring the potential difference concept was selected and both a and $b$ parts of the question were analyzed. Questions were administered to 399 students who were registered at Ballkesir University Science Teacher Education department. As a result of the analysis of the data, it has been determined that majority of the students have the misconception about the potential difference and that the misconception of this concept is common.
\end{abstract}

Keywords: Electricity, misconceptions, potential difference, teacher candidates.

\footnotetext{
* Bengisu ABACI, bengisuabaci@gmail.com, http://orcid.org/0000-0002-4381-0586 Mustafa Sabri KOCAKÜLAH, sabriko@ balikesir.edu.tr, http://orcid.org/0000-0002-4119-8477
} 


\section{Giriş}

Yapılan araştırmalarda öğrencilerin fen dersleri başarısının diğer derslere göre daha düşük olduğu ve ögrencilerde motivasyon ile ilginin istenilen derecede olmadığı gözlemlenmiştir. [1, 2]. Bunun nedeni olarak fen derslerinde kullanılan kavramların daha soyut olması ve öğrencilerin bu kavramları anlamlandırmakta güçlük çekmesi gösterilmektedir $[3,4]$. Fizik eğitimi alanında yapılan araştırma sonuçları öğrencilerin kavramları adlandırmada yaşadıkları güçlüklerden dolayı bilim insanlarının kabul ettiği tanımlardan farklı tanımları kabul ettiklerini ortaya koymaktadır. Bu durumdan dolayı 1980'li yıllardan günümüze kadar fen derslerinde öğretilen konularda geçen kavramlara ait kavram yanılgılarını belirlemek ve bu kavram yanılgılarını değiştirmek ya da iyileştirmek amaçlı birçok çalışma yapılmıştır [5-11].

Öğrencilerin kavramlar ile ilgili sahip oldukları bilimsel olarak tamamen yanlış olan tanımlar "kavram yanılgısı" olarak adlandırılmaktadır. Eğer bir öğrenci bilimsel olarak yanlış ifade edilen tanımda 1srarc1, bu tanımı tamamen kabul ediyor ve tanımını gerekçeleri ile açıklayarak kendinden emin ifadeler veriyor ise bu durumda kavram yanılgısından bahsedilebilir [12]. $\mathrm{Bu}$ anlamda kavram yanılgısı, bir kişinin bir kavramı anlama şeklinin, ortaklaşa kabul edilen bilimsel anlamından önemli derecede farklılık göstermesi şeklinde de ifade edilebilir [13].

Elektrik konusunda farklı sınıf düzeylerinde birçok çalışma yapılmıştır. Yapılan bir çalışmada Ankara il merkezindeki 12 ilköğretim okulunun 6., 7. ve 8 . sınıflarında öğrenim gören 1162 öğrenci ile çalışılmıştır. Çalışma verilerinin analizi sonucunda öğrencilerin elektrik akımı konusunda birçok kavram yanılgılarının olduğu ve 6., 7. ve 8. sınıf öğrencilerinin elektrik konusunda benzer yanılgılara sahip oldukları tespit edilmiştir [14]. Lise düzeyinde yapılan çalışmalarda da öğrencilerin elektrik konusunda kavram yanılgılarına sahip olduğu belirlenmiştir. $\mathrm{Bu}$ gruptaki çalışmalarda $[15,16]$ elektrik konusu ile kavram yanılgıları araştırılırken aynı zamanda kavramsal değişim yaklaşımı altında kavramsal değişim metinleri gibi öğretim araçları kullanılarak ortaya çıkarılan kavram yanılgılarının iyileştirilmesine dönük öğretim planlarının etkisine bakılmıştır. Üniversitelerde yapılan çalışmalarda da öğrencilerin elektrik devreleri konusunda kavram yanılgıları olduğu tespit edilmiştir. Özellikle üniversite düzeyinde yapılan çalışmalar ile lise öğrencilerinde ve üniversite öğrencilerinde bulunan kavram yanılgılarının benzerlik gösterdiği de belirlenmiştir [17].

Elektrik konusunda yapılan çalışmalar içinde potansiyel fark kavramına ayrıca odaklanan araştırmacılar, öğrencilerin potansiyel farkı 'devrede akım gibi dolaşır', 'devrede akar' şeklinde tanımladıklarına vurgu yapmaktadırlar. Bu türden kavram yanılgısı 'potansiyel fark akım özelliği gösterir' şeklinde tanımlanmıştır [18,19]. Bunun yanında yapılan literatür taramasında fizik eğitiminde yüksek lisans yapan öğrencilerin devredeki lambanın potansiyel farkı harcadığı ve akımın potansiyel fark oluşturduğu şeklinde kavram yanılgılarına sahip oldukları da rapor edilmiștir [19]. Potansiyel farkı pile bağlayıp pil sayısı değişmediği sürece potansiyel farkın değişmeyeceğini düşünen öğrenciler de bulunmaktadır [16]. Bu türde düşünceye sahip olan öğrencilerin pil değişmediği sürece devrede yapılan değişikliğin diğer devre elemanları üzerinde değişikliğe sebep olup olmayacağını yorumlayamadıkları anlaşılmaktadır.

$\mathrm{Bu}$ çalışmanın amacı, öğretmen olmak üzere atanacak son sınıf üniversite öğrencilerinin potansiyel fark kavramı ile ilgili düşüncelerini belirlemektir. Çalışma potansiyel fark kavramının son sınıf öğrencileri tarafından ne derecede ve hangi düzeyde anlaşıldığının ortaya konulması, üniversite eğitiminin son yılına gelmiş aynı zamanda ögretmen olmak üzere atanacak öğrencilerin potansiyel fark kavramı ile ilgili kavramsal anlamalarının hangi düzeyde olduğunun ve bu kavramsal anlamalarının kavram yanılgısı içerip içermediğini belirlenmesi açısından önemlidir. Özellikle potansiyel fark kavramına odaklanan çalışmaların nispeten az olması da dikkati çeken bir başka noktadır. $\mathrm{Bu}$ açıdan potansiyel fark kavramının öğretimi ile ilgili olarak öğretmenlere ve bu alanda çalışanlara önerilerde bulunmak açısından çalışmanın önemli olduğu düşünülmektedir.

$\mathrm{Bu}$ araştırmada üniversite öğrencilerinin potansiyel fark kavramı ile ilgili kavram yanılgılarını belirlemek amaçlanmıştır. Bu amaca ulaşmak için aşağıda verilen sorulara yanıt aranmıştır.

1. Potansiyel fark kavramı ile ilgili üniversite son sınıf öğrencilerinin sahip olduğu kavram yanılgıları nelerdir?

2. Öğrencilerin kavram yanılgıları yıllara göre değişim göstermekte midir?

\section{Yöntem}

Çalışmada nitel araştırma yöntemi kullanılmıştır. Araştırmada elde edilen veriler kategorilere ayrılarak her bir kategori yüzdelikler halinde frekans analizi yapılarak incelenmiştir. Bu bölüm altında sırasıyla çalışma grubu, veri toplama aracı, süreci ve veri analiz yöntemi açıklanmaktadır. 


\section{1. Çalışma grubu}

Bu çalışmada, 2006-2007, 2007-2008, 2008-2009, 2011-2012， 2012-2013， 2013-2014， 2014-2015, 2015-2016, 2016-2017 eğitim-öğretim yıllarında Balıkesir Üniversitesi Necatibey Eğitim Fakültesi Fen Bilgisi Öğretmenliği bölümünde okuyan 299 son sınıf öğrencileri ile çalışılmıştır. İlgili fakültede öğrenim gören son sınıf öğrencileri sayısı sınırlı olduğundan daha fazla öğrenciye erişerek öğrenci sayısını arttırıp daha geniş bir kitleden gelen verilerin birleştirilerek araştırma bulgularının geçerliğini arttırmak amacı ile dokuz yıllık süreçte toplanan anket verileri kullanılmıştır.

\subsection{Veri toplama aract}

Öğrencilerdeki kavram yanılgılarını belirlemek için birçok araştırmada çoktan seçmeli testler kullanılmaktadır. Ancak öğrenci çoktan seçmeli soruda niçin o cevabı verdiğinden bahsetmediği için tam olarak kavram yanılgısına sahip olduğundan bahsedilemez. Çünkü çoktan seçmeli sorularda öğrencilerdeki kavram yanılgısı şıklarla sınırlıdır ve öğrencinin gerçek düşüncesini tam olarak yansitıp yansıtmadığ testlerde öğrenciye neden niçin soruları yansıtılmalıdır ki öğrenci ifadelerinin tam olarak kavram yanılgısı şeklinde nitelendirilip nitelendirilemeyeceğine karar verilebilsin. $\mathrm{Bu}$ araştırmada bu nedenle çoktan seçmeli sorunun altına eklenen açık uçlu soru ile çoktan seçmeli açıklamalı soru türü kullanılmıştır.

Araştırmada veri toplama aracı olarak; literatürdeki kavram yanılgılarından yararlanılarak oluşturulan ve sekiz açıklamalı-çoktan seçmeli test soruları içeren anket birinci araştırmacı tarafından hazırlanmıştır. Testte öğrencilere elektrikle ilgili kavram yanılgılarını belirlemek amaçlı sorular sorulmuştur. Sorular lamba parlaklığını etkileyen etmenler, akım kavramı, potansiyel fark kavramı, direnç kavramı ve akım şiddeti kavramını içermektedir. Bu çalışmada sadece potansiyel fark kavramını içeren sorular kullanılarak öğrencilerin açıklamaları incelenmiştir. Potansiyel fark kavramı ile ilgili sorular Shipstone ve diğ. [22] tarafından yapılan çalışmadan alınmıştır.

\subsection{Veri toplama süreci}

Yapılan çalışmaya ait veriler dokuz yıllık süreci kapsamakta olup üniversite son sınıf öğrencilerine ilgili yılın bahar döneminde açılan "Fizikte Kavram Yanılgıları" dersinde elektrik konuları işlenmeden önce birinci araştırmacı tarafından uygulanmıştır.

\subsection{Verilerin analizi}

$\mathrm{Bu}$ çalışmada kullanılan kavramsal anlama testinde açıklama gerektiren açık uçlu sorular kullanılmıştır. Testteki sekiz sorudan 5. soru seçilip a ve b şıkları incelenmiştir. $\mathrm{Bu}$ sorularda "potansiyel fark" kavramı analiz edilmiştir. Öğrencilerin vermiş olduğu yanıtlar tek tek incelenmiş ve verilen yanıtlara göre içerik analizi yapılarak yanıt kategorileri oluşturulmuştur. Her sorunun çoktan seçmeli kısmına verilen yanıtlar "Doğru Yanıt" ve "Yanlış Yanıt" olarak kategorilendirilmiştir. Aşağıda doğru yanıt verenlerin açıklamalarına ait alt gruplar ilgili alt gruba ait örnek öğrenci yanıtları eşliğinde sunulmaktadır.

- Tam doğru açıklamalar içeren ifadeler - Doğru Cevap Bilimsel Tam Doğru Açıklama,

Ö12-20: $1-2$ ve 3-4 arasında direnç çok küçük oluğundan önemsenmez. 2-3 arasinda lamba direncinden dolayı bir potansiyel fark oluşur. $\mathrm{Bu}$ da 6V'dur. (Doğru Cevap Bilimsel Tam Doğru Açıklama)

- Kısmen doğru ifadeler yani tam doğru açıklamaya göre eksik açıklamalar içeren öğrenci yanıtları - Doğru Cevap Bilimsel Kısmen Doğru Açıklama,

Ö07-10: Direnç geçen telin yani 2-3 arsının potansiyel farkı $6 \mathrm{~V}$ olacak, diğerlerinde bir direnç olmadığından sıfır olacaktır. (Doğru Cevap Bilimsel Kısmen Doğru Açıklama)

- Elektrik konusu ile ilgili olup ancak açıklamasında bilimsel anlamda doğruluk değeri bulunmayan öğrenci ifadeleri - Doğru Cevap Bilimsel İlgili Açıklama,

Ö06-2: Akımın bir voltaj oluşturması için dirençten geçmesi gerekir. $\mathrm{Bu}$ nedenden dolayı C şıkkı doğru. (Doğru Cevap Bilimsel İlgili Açıklama)

- Sorunun açıklanmasında anlaşılır ifadeler kullanılmamış - Doğru Cevap Kodlanamaz Açıklama,

Ö07-2: Yukarıdaki ile aynı V=i x R. (Doğru Cevap Kodlanamaz)

- Açıklama kısmının boş bırakılarak herhangi bir ifadenin yazılmaması - Doğru Cevap Açıklama Yok

Öte yandan, yanlış yanıt verenlerin açıklamalarına ait alt gruplar aşağıda belirtildiği gibi düzenlenmiştir.

- Tam doğru açıklamalar içeren ifadeler - Yanlış Cevap Bilimsel Tam Doğru Açıklama,

- Kısmen doğru açıklamalar içeren öğrenci yanıtları - Yanlış Cevap Bilimsel Kısmen Doğru Açıklama,

- Elektrik konusu ile ilgili olup ancak açıklamasında bilimsel anlamda doğruluk değeri bulunmayan öğrenci ifadeleri - Yanlış Cevap Bilimsel İlgili Açıklama,

Ö08-6: V= I x R üretecin ürettiği potansiyel fark devrenin her tarafinda aynı olur. Yukarıdaki formülden de anlaşılacağı gibi $\mathrm{R}$ değeri değişmesi ile I yani akım değişir. (Yanlış Cevap Bilimsel İlgili Açıklama) 
- Sorunun açıklanmasında anlaşılır ifadeler kullanılmamış - Yanlış Cevap Kodlanamaz Açıklama,

Ö13-35: Değişmez. (Yanlış Cevap Kodlanamaz Açıklama)

- Açıklama kısmının boş bırakılarak herhangi bir ifadenin yazılmaması - Yanlış Cevap Açıklama Yok

Yukarıda verilen kategorilendirmeler dişında cevapsız bırakılan sorular için "Cevap Yok Açıklama Yok' kategorisi oluşturulmuştur. Verilen kategoriler içinde Elektrik konusu ile ilgili olup ancak açıklamasında bilimsel anlamda doğruluk değeri bulunmayan öğrenci ifadeleri kavram yanılgıları içeren yanıt kategorilerini oluşturmaktadır. Bu kategoriler analiz tablolarında 'Doğru Cevap Bilimsel İlgili Açıklama' ve 'Yanlış Cevap Bilimsel İlgili Açıklama' başılıları ile belirtilmiştir. Her soruya verilen öğrenci yanıtlarının kategorilendirilmesi tamamlandıktan sonra oluşturulan tablolar ile kategoriler tek tek incelenip öğrenci yanıtlarının dağılımına ilişkin yorum yapılmıştır.

\section{Bulgular}

Yapılan çalışma sonucunda iki sorudan elde edilen verilere ait analiz bulguları öğrenci sayıları ve yüzdelik frekanslar halinde iki ayrı tabloda sunulmuştur. Aşağıda her bir soru için veriler ayrı ayrı verilmektedir.

\subsection{Birinci soru için bulgular}

Birinci soruda öğrencilere basit bir elektrik devresinin belli noktaları arasındaki potansiyel farklar sorulmuştur. Öğrencilerin verilen noktalar arasındaki potansiyel fark değerlerini belirlemeleri ve neye dayanarak bu seçimi yaptıklarını açıklamaları istenmiştir. Birinci soru aşağıdaki şekilde verildiği gibidir.

Aşağıda verilen her iki devredeki lambalar özdeştir. Her bir devrenin istenen iki noktası arasındaki potansiyel farkı ile ilgili olarak aşağıda verilen yanıtların başındaki kutucuklardan size göre doğru olanın içine X işareti koyunuz. Verdiğiniz cevabı kısaca açıklayınız.

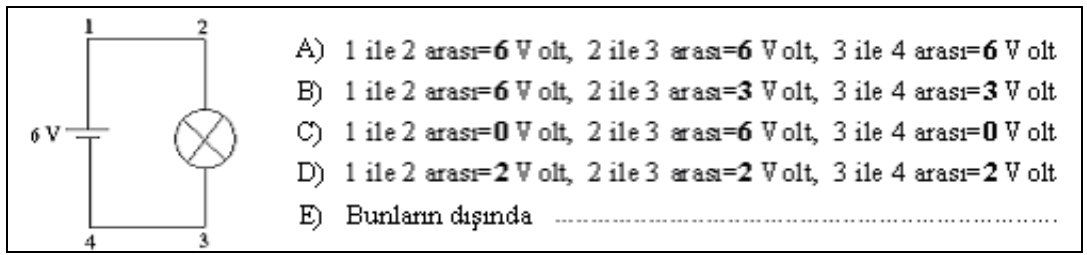

(a) Bu şıkkı seçtim çünkü

Şekil 1: Potansiyel fark kavramı ile ilgili birinci soru

Birinci sorunun tam doğru cevabı aşağıdaki gibidir.

(a). Ohm yasasına göre potansiyel fark, akım ve direncin çarpımına eşittir $(V=I x R)$. Bu yasaya göre 1-2 arasında teldeki direnç yok denecek kadar azdir ve ihmal edildiği için potansiyel fark sıfira eșittir. 2-3 arasında ampul direnci ihmal edilemez ve akım çarpı direnç dediğimizde direncin uçları arasında potansiyel fark vardır ve bu üretecin uçları arasındaki potansiyel farka eşittir. 3-4 arasında 1-2 arasındaki durumda olduğu gibi direncin ihmalinden dolayı potansiyel fark sıfıra eşittir. Cevap C'dir.

Yukarıda verilen bilimsel olarak tam doğru cevaba göre birinci soruya verilen öğrenci yanıtlarına ilişkin analiz sonuçları Tablo 1' de sunulmuştur.
Tablo 1'i incelediğimizde Yanlış Cevap Bilimsel İlgili Açıklama kategorisindeki kavram yanılgısı içeren öğrenci yanıtlarının günümüz yıllarına gelindiğinde fazlalaştı̆̆ını görüyoruz. Bir başka değişle, 2006-2007 yıllarında doğru cevap yüzdesi $\% 63$ iken bu oran 2016-2017 yıllarında yüzde \%5'e düşmüştür. Öğrencilerin genel anlamda telin direncini göz ardı ettikleri ve bundan dolayı tam doğru değil de kısmen doğru yanıt fazlalığının oluştuğu anlaşılmaktadır. Ancak günümüz yıllarına yaklaştıkça öğrencilerin kavram yanılgısının daha fazla olduğu, sorunun cevabını bile yanlış verdikleri tespit edilmiştir. Telin direncinin olmaması kavram yanılgısının çoğunlukla devrenin her yerinde potansiyel farkın aynı olduğu düşüncesinden dolayı ortaya çıktığı tespit edilmiştir. Aşağıda her bir yanıt kategorisine ilişkin örnek öğrenci yanıtları sunulmuştur. 
Ö06-29: telin direncini (iletken telin) 0 kabul edince $\mathrm{V}=\mathrm{I} \times \mathrm{R}$ olduğundan akım ne olursa olsun $1-2$ ve $3-4$ aras $V=0$ olur. 2-3 arası ise $6 \mathrm{~V}$ olacaktır. (Doğru Cevap Bilimsel Tam Doğru Açıklama)

Ö12-5: Devredeki potansiyel fark 2 ile 3 arasinda $6 \mathrm{~V}$ olur. 1 ile 2 ve 3 ile 4 arasinda direnç olmadığından potansiyel fark oluşmaz. (Doğru Cevap Kısmen Doğru Açıklama)

Ö12-32: 1 ve 2, 3 ve 4 arasında pil bağlı yoktur. Bu yüzdende potansiyel değeri “ 0 " olur. (Doğru Cevap Bilimsel İlgili Açıklama)
Ö14-17: Potansiyel fark lambayı yakar ve devreyi tamamlar değişiklik olmaz. (Doğru cevap Bilimsel İlgili Açıklama)

Ö08-10: Potansiyel fark aynı olması gerekir. Devreyi akım dolandığı için potansiyel fark değişmez. (Yanlış Cevap Bilimsel İlgili Açıklama)

Ö11-4: Emin değilim. (Yanlış Cevap Kodlanamaz Açıklama)

Tablo 1. Birinci soru için öğrencilerin verdikleri yanıtların yıllar bazında kategorilere göre dağılımı.

\begin{tabular}{|c|c|c|c|c|c|c|c|c|c|}
\hline \multirow[b]{3}{*}{ Yanıt Türüi } & \multicolumn{9}{|c|}{ Öğrenci Yanıtları N (\%) } \\
\hline & \multicolumn{9}{|c|}{ Yıllar } \\
\hline & $\begin{array}{l}2006- \\
2007 \\
\end{array}$ & $\begin{array}{l}2007- \\
2008 \\
\end{array}$ & $\begin{array}{c}2008- \\
2009 \\
\end{array}$ & $\begin{array}{c}2011- \\
2012 \\
\end{array}$ & $\begin{array}{c}2012- \\
2013 \\
\end{array}$ & $\begin{array}{c}2013- \\
2014 \\
\end{array}$ & $\begin{array}{l}2014- \\
2015 \\
\end{array}$ & $\begin{array}{l}2015- \\
2016 \\
\end{array}$ & $\begin{array}{l}2016- \\
2017 \\
\end{array}$ \\
\hline Doğru Cevap & $\begin{array}{c}34 \\
(63.00)\end{array}$ & $\begin{array}{c}28 \\
(66.70)\end{array}$ & $\begin{array}{c}24 \\
(72.70)\end{array}$ & $\begin{array}{c}12 \\
(52.20)\end{array}$ & $\begin{array}{c}16 \\
(72.70)\end{array}$ & $\begin{array}{c}10 \\
(28.60)\end{array}$ & $\begin{array}{c}13 \\
(32.50)\end{array}$ & $\begin{array}{c}1 \\
(5.00)\end{array}$ & $\begin{array}{c}1 \\
(5.00)\end{array}$ \\
\hline $\begin{array}{l}\text { Doğru Cevap Bilimsel } \\
\text { Tam Doğru Açlklama }\end{array}$ & $\begin{array}{c}2 \\
(3.70)\end{array}$ & $\begin{array}{c}1 \\
(2.40)\end{array}$ & $\begin{array}{c}2 \\
(6.10)\end{array}$ & 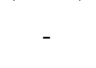 & $\begin{array}{c}1 \\
(4.50)\end{array}$ & 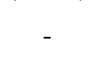 & - & - & - \\
\hline Doğru Cevap Bilimsel & 24 & 24 & 20 & 9 & 11 & 4 & 10 & 1 & 1 \\
\hline Kısmen Doğru Açıklama & $(44.40)$ & $(57.10)$ & $(60.60)$ & $(39.10)$ & $(50.00)$ & $(11.40)$ & $(25.00)$ & $(5.00)$ & $(5.00)$ \\
\hline $\begin{array}{c}\text { Doğru Cevap Bilimsel } \\
\text { İlgili Açıklama }\end{array}$ & $\begin{array}{c}8 \\
(14.80)\end{array}$ & $\begin{array}{c}2 \\
(4.80)\end{array}$ & $\begin{array}{c}2 \\
(6.10)\end{array}$ & $\begin{array}{c}2 \\
(8.70)\end{array}$ & $\begin{array}{c}3 \\
(13.60)\end{array}$ & $\begin{array}{c}5 \\
(14.30)\end{array}$ & $\begin{array}{c}2 \\
(5.00)\end{array}$ & - & - \\
\hline $\begin{array}{l}\text { Doğru Cevap } \\
\text { Kodlanamaz }\end{array}$ & - & $\begin{array}{c}1 \\
(2.40)\end{array}$ & - & - & - & - & $\begin{array}{c}1 \\
(2.50)\end{array}$ & - & - \\
\hline $\begin{array}{c}\text { Doğru Cevap Açıklama } \\
\text { Yok }\end{array}$ & - & - & - & $\begin{array}{c}1 \\
(4.30)\end{array}$ & $\begin{array}{c}1 \\
(4.50)\end{array}$ & $\begin{array}{c}1 \\
(2.85)\end{array}$ & - & - & - \\
\hline Yanlış cevap & $\begin{array}{c}19 \\
(35.20)\end{array}$ & $\begin{array}{c}14 \\
(33.30)\end{array}$ & $\begin{array}{c}9 \\
(27.30)\end{array}$ & $\begin{array}{c}11 \\
(47.80)\end{array}$ & $\begin{array}{c}6 \\
(27.30)\end{array}$ & $\begin{array}{c}24 \\
(68.60)\end{array}$ & $\begin{array}{c}26 \\
(65.00)\end{array}$ & $\begin{array}{c}17 \\
(85.00)\end{array}$ & $\begin{array}{c}19 \\
(95.00)\end{array}$ \\
\hline $\begin{array}{l}\text { Yanlış Cevap Bilimsel } \\
\text { Tam Doğru Açıklama }\end{array}$ & - & - & - & - & - & - & - & - & - \\
\hline $\begin{array}{c}\text { Yanlış Cevap Bilimsel } \\
\text { Kısmen Doğru Açıklama }\end{array}$ & - & - & - & - & - & - & - & - & - \\
\hline $\begin{array}{c}\text { Yanlış Cevap Bilimsel } \\
\text { İlgili Açılama }\end{array}$ & $\begin{array}{c}19 \\
(35.20)\end{array}$ & $\begin{array}{c}14 \\
(33.30)\end{array}$ & $\begin{array}{c}9 \\
(27.30)\end{array}$ & $\begin{array}{c}9 \\
(39.10)\end{array}$ & $\begin{array}{c}6 \\
(27.30)\end{array}$ & $\begin{array}{c}22 \\
(62.85)\end{array}$ & $\begin{array}{c}22 \\
(55.00)\end{array}$ & $\begin{array}{c}14 \\
(70.00)\end{array}$ & $\begin{array}{c}19 \\
(95.00)\end{array}$ \\
\hline $\begin{array}{c}\text { Yanlış Cevap } \\
\text { Kodlanamaz Açıklama }\end{array}$ & - & - & - & $\begin{array}{c}2 \\
(8.70)\end{array}$ & - & 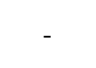 & $\begin{array}{c}2 \\
(5.00)\end{array}$ & - & - \\
\hline $\begin{array}{c}\text { Yanlış Cevap Açıklama } \\
\text { Yok }\end{array}$ & - & - & - & - & - & $\begin{array}{c}2 \\
(5.70)\end{array}$ & $\begin{array}{c}2 \\
(5.00)\end{array}$ & $\begin{array}{c}3 \\
(15.00)\end{array}$ & - \\
\hline $\begin{array}{c}\text { Cevap Yok Açıklama } \\
\text { Yok }\end{array}$ & $\begin{array}{c}1 \\
(1.80) \\
\end{array}$ & - & - & - & - & $\begin{array}{c}1 \\
(2.90) \\
\end{array}$ & $\begin{array}{c}1 \\
(2.50) \\
\end{array}$ & $\begin{array}{c}2 \\
(10.00) \\
\end{array}$ & - \\
\hline
\end{tabular}

Birinci soruya verilen öğrenci yanıtları genel olarak incelendiğinde; lambanın potansiyel farkı harcadığını düşünen öğrenciler bulunmaktadır. Bunun yanında lambayı direnç olarak görmeyip 'Devrede direnç yoktur. Potansiyel fark azalmaz yani harcanmaz bundan dolayı her yerde potansiyel fark 6V' tur' şeklinde açıklamada bulunan öğrenciler de vardır. Potansiyel farkın değişmeyip sabit kalacağı fikrini dirence değil de pil sayısına bağlayan öğrenciler 'pil sayısı değişmediği için potansiyel fark değişmez' şeklinde yanıt vermişlerdir. Devrenin her yerinde potansiyel farkın sabit kaldığı düşüncesini akıma bağlayan öğrenciler teste verdikleri yanıtlarında 'devre üzerinden geçen akım değişmediği için potansiyel fark değişmez' açıklamasında bulunmuşlardır.

\subsection{Ikinci soru için bulgular}

İkinci soruda öğrencilere yine basit bir elektrik devresinin belli noktaları arasındaki potansiyel farkları sorulmuştur. Öğrencilerin bir önceki sorudan farklı olarak devreye ikinci bir direnç seri bağlı olarak eklendiğinde verilen noktalar arasındaki potansiyel fark değerlerini belirlemeleri ve neye dayanarak bu seçimi yaptıklarını açıklamaları istenmiştir. Çalışmada kullanılan ikinci soru Şekil 2' de verilmiştir. 
Aşağıda verilen her iki devredeki lambalar özdeştir. Her bir devrenin istenen iki noktası arasındaki potansiyel farkı ile ilgili olarak aşağıda verilen yanıtların başındaki kutucuklardan size göre doğru olanın içine $\mathrm{X}$ işareti koyunuz. Verdiğiniz cevabı kısaca açıklayınız.

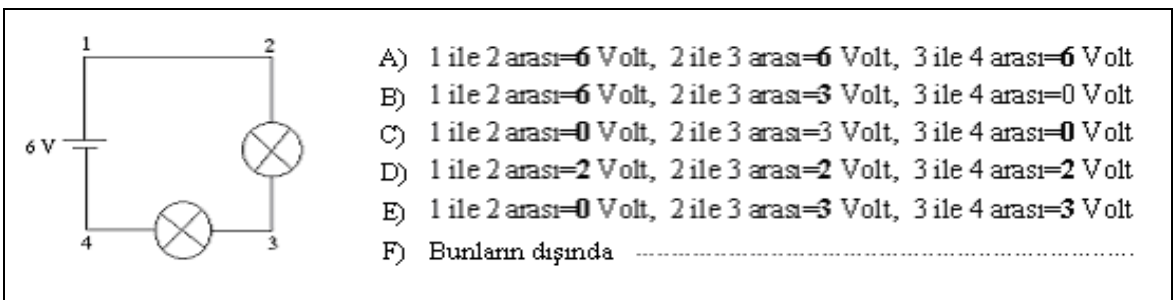

(a) Bu şıkkı seçtim çünkü

Şekil 2: Potansiyel fark kavramı ile ilgili ikinci soru

Sorunun tam doğru cevabı aşağıdaki gibidir.

(b). Ohm yasasına göre potansiyel fark akım ve direncin çarpımına eşittir $(V=I \times R)$. Bu yasaya göre 1-2 arasında teldeki direnç yok denecek kadar azdır ve ihmal edildiği için potansiyel fark sıfira eşittir. 2-3 ve 3-4 arasında lambaların direnci ihmal edilemez ve akım çarpı direnç formülü kullanıldı̆̆ında potansiyel fark vardır. Ancak seri bağlı devrede ampuller özdeştir ve potansiyel farkı eş olarak paylaşırlar. Toplam potansiyel fark $6 \mathrm{~V}$ ve ampullere eşit olarak dağılır. 2-3 arasında 3V, 3-4 arasında 3 V olacaktır. Cevap E'dir.

İkinci sorunun analizi sonucunda elde edilen veriler Tablo 2' de verilmiştir. Tablo 2'yi incelediğimizde Yanlış Cevap Bilimsel İlgili Açılama kategorisindeki kavram yanılgısı içeren öğrenci yanıtlarının günümüz yıllarına gelindiğinde fazlalaştığını görüyoruz. Bir başka değişle 20062007 yıllarında doğru cevap yüzdesi \% 63 iken bu oran 2016-2017 yıllarında yüzde \% 5'e düşmüştür.

Birinci soru ile elde edilen bulguların aynısı ikinci sorunun analizi sonucunda da karşımıza çıkmaktadır. Öğrenciler özellikle devrenin her yerinde potansiyel farkın aynı olacağı açıklamasını yapmaktadırlar. Bu gruptaki öğrenciler direnci hiçe sayarak devredeki potansiyel farkın değişmeyeceğini belirtmektedirler. Ayrıca seri bağlı ve paralel bağlı devreler arasındaki farkın oluşturulamadığı anlaşılmaktadır. Öğrenciler seri bağlı devreyi paralel bağlı gibi düşünüp işlemler yapmışlardır. Bu türden işlem yapan öğrenciler sayıca fazla olup her nokta arasındaki potansiyel farkı değişmez ve $6 \mathrm{~V}$ olarak tanımladıkları dikkati çekmektedir. Aşağıda her bir yanıt kategorisine ilişkin örnek öğrenci yanıtları sunulmuştur.

Ö06-29: 1-2 arası üst soruda da olduğu gibi telin direncini sıfır kabul edince $V=0$ olur. $2-3$ ve 3-4 özdeş iki lamba vardır. Bunlar için V1 + V2=6V V'ler ortak çünkü lambalar özdeş öyleyse $6 / 2=3$ volt her ikisi de aynı. (Doğru Cevap Bilimsel Tam Doğru Açıklama)

Ö13-14: 1 ile 2 arası 0 volttur. Çünkü burada akım bir direnç ile karşılaşmaz direnç 0'dır. 2 ile 3 ve 3 ile 4 arasında ise seri bağlı olduğundan 6volt'u eşit olarak paylaşır. (Doğru Cevap Bilimsel Kısmen Doğru Açılama)

Ö08-20: Lambaların üzerinde potansiyel gerilim oluşacaktır. (Doğru Cevap Bilimsel İlgili Açıklama)

Ö07-6: E şıkkı. Tam olarak e varlığı ile ilgili bir durum. (Doğru Cevap Kodlanamaz)

Ö08-9: Devrenin bir ucundan diğer bir ucu arasındaki potansiyel fark her bir uç arasında eşittir. (Yanlış Cevap Bilimsel İlgili Açıklama)

İkinci soruda birden fazla direnç kullanıldığında bazı öğrencilerin lambanın olduğu 2-3 ve 3-4 noktaları arasında potansiyel fark bölünür diyerek $6 \mathrm{~V}$ luk gerilimi iki lambaya bölüştürürken direncin olmadığı 1-2 noktaları arasındaki bölüme 6V' luk potansiyel farkı ataması yaptıkları da gözlenmiştir. Çalışmanın bundan sonraki kısmında elde edilen bulgular 1şında ortaya çıkan sonuçlar tartışılıp konunun öğretimine dönük önerilerde bulunulmuştur. 
Tablo 2. İkinci soru için öğrencilerin verdikleri yanıtların yıllar bazında kategorilere göre dağılımı.

\begin{tabular}{|c|c|c|c|c|c|c|c|c|c|}
\hline \multirow[b]{3}{*}{ Yanıt Türü } & \multicolumn{9}{|c|}{ Öğrenci Yanıtları N(\%) } \\
\hline & \multicolumn{9}{|c|}{ Yillar } \\
\hline & $\begin{array}{l}2006- \\
2007\end{array}$ & $\begin{array}{l}2007- \\
2008\end{array}$ & $\begin{array}{c}2008- \\
2009\end{array}$ & $\begin{array}{l}2011- \\
2012\end{array}$ & $\begin{array}{l}2012- \\
2013\end{array}$ & $\begin{array}{l}2013- \\
2014\end{array}$ & $\begin{array}{l}2014- \\
2015\end{array}$ & $\begin{array}{l}2015- \\
2016\end{array}$ & $\begin{array}{l}2016- \\
2017\end{array}$ \\
\hline Doğru Cevap & $\begin{array}{c}34 \\
(63.00)\end{array}$ & $\begin{array}{c}27 \\
(64.30)\end{array}$ & $\begin{array}{c}25 \\
(75.70)\end{array}$ & $\begin{array}{c}9 \\
(39.10)\end{array}$ & $\begin{array}{c}15 \\
(68.20)\end{array}$ & $\begin{array}{c}10 \\
(28.60)\end{array}$ & $\begin{array}{c}22 \\
(55.00)\end{array}$ & $\begin{array}{c}2 \\
(10.00)\end{array}$ & $\begin{array}{c}1 \\
(5.00)\end{array}$ \\
\hline $\begin{array}{c}\text { Doğru Cevap Bilimsel Tam } \\
\text { Doğru Açıklama }\end{array}$ & $\begin{array}{c}1 \\
(1.80)\end{array}$ & - & $\begin{array}{c}2 \\
(6.10)\end{array}$ & - & $\begin{array}{c}1 \\
(4.50)\end{array}$ & - & - & - & - \\
\hline $\begin{array}{c}\text { Doğru Cevap Bilimsel } \\
\text { Kısmen Doğru Acıklama }\end{array}$ & $\begin{array}{c}29 \\
(53.70)\end{array}$ & $\begin{array}{c}24 \\
(57.10)\end{array}$ & $\begin{array}{c}21 \\
(63.60)\end{array}$ & $\begin{array}{c}7 \\
(30.40)\end{array}$ & $\begin{array}{c}11 \\
(50.00)\end{array}$ & $\begin{array}{c}7 \\
(20.00)\end{array}$ & $\begin{array}{c}15 \\
(37.50)\end{array}$ & $\begin{array}{c}1 \\
(5.00)\end{array}$ & - \\
\hline $\begin{array}{l}\text { Doğru Cevap Bilimsel } \\
\text { İlgili Accıklama }\end{array}$ & $\begin{array}{c}4 \\
(7.40)\end{array}$ & $\begin{array}{c}1 \\
(2.40)\end{array}$ & $\begin{array}{c}1 \\
(3.00)\end{array}$ & $\begin{array}{c}1 \\
(4.30)\end{array}$ & $\begin{array}{c}2 \\
(9.10)\end{array}$ & $\begin{array}{c}2 \\
(5.70)\end{array}$ & $\begin{array}{c}5 \\
(12.50)\end{array}$ & $\begin{array}{c}1 \\
(5.00)\end{array}$ & - \\
\hline $\begin{array}{l}\text { Doğru Cevap } \\
\text { Kodlanamaz }\end{array}$ & - & $\begin{array}{c}2 \\
(4.80)\end{array}$ & $\begin{array}{c}1 \\
(3.00)\end{array}$ & - & - & - & $\begin{array}{c}2 \\
(5.00)\end{array}$ & - & - \\
\hline $\begin{array}{c}\text { Doğru Cevap Açılklama } \\
\text { Yok }\end{array}$ & - & - & - & $\begin{array}{c}1 \\
(4.30)\end{array}$ & $\begin{array}{c}1 \\
(4.50)\end{array}$ & $\begin{array}{c}1 \\
(2.85)\end{array}$ & - & - & $\begin{array}{c}1 \\
(5.00)\end{array}$ \\
\hline Yanlış cevap & $\begin{array}{c}18 \\
(33.30)\end{array}$ & $\begin{array}{c}14 \\
(33.30)\end{array}$ & $\begin{array}{c}8 \\
(24.20)\end{array}$ & $\begin{array}{c}14 \\
(60.90)\end{array}$ & $\begin{array}{c}16 \\
(72.70)\end{array}$ & $\begin{array}{c}22 \\
(62.90)\end{array}$ & $\begin{array}{c}14 \\
(35.00)\end{array}$ & $\begin{array}{c}16 \\
(80.00)\end{array}$ & $\begin{array}{c}18 \\
(90.00)\end{array}$ \\
\hline $\begin{array}{l}\text { Yanlış Cevap Bilimsel } \\
\text { Tam Doğru Açklama }\end{array}$ & - & - & - & - & - & - & - & - & - \\
\hline $\begin{array}{c}\text { Yanlış Cevap Bilimsel } \\
\text { Kısmen Doğru Açıklama }\end{array}$ & - & - & - & - & - & - & - & - & - \\
\hline $\begin{array}{c}\text { Yanlış Cevap Bilimsel } \\
\text { İlgili Açıklama }\end{array}$ & $\begin{array}{c}17 \\
(31.50)\end{array}$ & $\begin{array}{c}13 \\
(30.90)\end{array}$ & $\begin{array}{c}7 \\
(21.20)\end{array}$ & $\begin{array}{c}12 \\
(52.20)\end{array}$ & $\begin{array}{c}15 \\
(68.20)\end{array}$ & $\begin{array}{c}16 \\
(45.70)\end{array}$ & $\begin{array}{c}12 \\
(30.00)\end{array}$ & $\begin{array}{c}9 \\
(45.00)\end{array}$ & $\begin{array}{c}17 \\
(85.00)\end{array}$ \\
\hline $\begin{array}{c}\text { Yanlış Cevap } \\
\text { Kodlanamaz Açıklama }\end{array}$ & $\begin{array}{c}1 \\
(1.80)\end{array}$ & $\begin{array}{c}1 \\
(2.40)\end{array}$ & $\begin{array}{c}1 \\
(3.00)\end{array}$ & - & - & $\begin{array}{c}2 \\
(5.70)\end{array}$ & $\begin{array}{c}1 \\
(2.50)\end{array}$ & $\begin{array}{c}2 \\
(10.00)\end{array}$ & $\begin{array}{c}1 \\
(5.00)\end{array}$ \\
\hline $\begin{array}{c}\text { Yanlış Cevap Açıklama } \\
\text { Yok }\end{array}$ & - & - & - & $\begin{array}{c}2 \\
(8.70)\end{array}$ & $\begin{array}{c}1 \\
(4.50)\end{array}$ & $\begin{array}{c}4 \\
(11.40)\end{array}$ & $\begin{array}{c}1 \\
(2.50)\end{array}$ & $\begin{array}{c}35 \\
(25.00)\end{array}$ & - \\
\hline Cevap Yok Açıklama Yok & $\begin{array}{c}2 \\
(3.70)\end{array}$ & $\begin{array}{c}1 \\
(2.40)\end{array}$ & - & - & $\begin{array}{c}1 \\
(4.50)\end{array}$ & $\begin{array}{c}3 \\
(8.60)\end{array}$ & $\begin{array}{c}4 \\
(10.00)\end{array}$ & $\begin{array}{c}2 \\
(10.00)\end{array}$ & $\begin{array}{c}1 \\
(5.00)\end{array}$ \\
\hline
\end{tabular}

\section{Sonuçlar ve tartışma}

Öğrencilerin bu çalışmada kullanılan sorulara verdikleri yanıtlardan devreye uygulanan potansiyel farkın dirençle oluştuğunu düşündükleri anlaşılmaktadır. Bunun yanında kablonun direncini yok sayarak 'direnç olmadığı için potansiyel fark sıfıra eşit olur' şeklinde kavram yanılgısına sahip oldukları anlaşılmaktadır. Yapılan açıklamalarda öğrenciler devredeki direnç değeri değişir ise potansiyel farkında değişeceği cevabını vermişlerdir. Bu türden kavram yanılgısı yapılan başka çalışmada da ortaya çıkmıştır [23]. Öğrenciler için temel sorun telin direncini yok saymaktır. Sorulara yanıt verirken işlemleri bu düşünceyle yapmışlardır. Teli dirençsiz kabul etme fikrinin yanında, seri bağlı devrelerde potansiyel farkın değişmediği, devrenin her noktasında aynı olduğu ve tel üzerinden de geçen akım olduğu sürece potansiyel farkın var olacağı düşüncesi çoğu ögrenci tarafından benimsenen bir görüştür. Bununla birlikte seri bağlı devrenin paralel bağlı devre ile karıştırılması ve iki devre türü arasındaki farkın kavranamaması durumu dikkate değer bir sonuçtur. Benzer sonuca literatürde başka araştırmalarda da rastlanmıştır [19]. Böyle bir sonuç, ortaokul ve lise yıllarındaki öğretimlerde ortaya çıkan kavram yanılgılarının üzerine düşülmemesi nedeniyle üniversite eğitiminde öğrenme güçlüklerinin devam etmesinin sebebi olarak düşünülebilir. $\mathrm{Bu}$ nedenle öğrencilere potansiyel fark konusunun öğretimini ilk defa yapacak fen bilimleri dersi öğretmenlerinin bu konuda kavram yanılgısına sahip olmamaları da önem taşımaktadır.

Araştırmanın bir başka çarpıcı sonucu da, tespit edilen kavram yanılgılarının 2006-2007 eğitim öğretim y1lından 2016-2017 eğitim öğretim y1lına doğru artış göstermesidir. $\mathrm{Bu}$ artışın en önemli nedeninin eğitim fakültesine giriş puanlarının düşmesi olduğu düşünülmektedir. Bunun yanında öğretim programlarındaki değişimler, kazanımların sayısının azaltılması ve ünite bazında öğrencilerin konuları birleştirmekte zorluklar yaşaması ve öğretmenlerin bu değişimlere ayak uydurma güçlüğü gibi etkenler neden olarak söylenebilir [23,24].

$\mathrm{Bu}$ çalışmada örneklem grubunun fen bilgisi öğretmen adayları olduğu düşünülürse, mesleğe adım atmadan önce fizik konularında sahip oldukları kavram yanılgılarının farkındalığının sağlanması ve bunların bilimsel gerçeklerle değiştirilebilmesine yönelik derslerin lisans programlarına zorunlu olarak dahil edilmesi önerilebilir. Aynı zamanda benzer uygulama fenin kimya ve biyoloji disiplin alanlarında da yapılabilir. Öğrencilerin saptanan kavram yanılgılarının düzeltilebilmesi için özellikle lisans programında Genel Fizik II ve laboratuvar derslerinde uygulamaya dönük öğretim planları oluşturulmalıdır. Özellikle potansiyel fark gibi oldukça soyut olan bu kavramın öğretiminde Tahmin Gözlem Açıklama tekniği gibi tekniklerle öğrencilerin düşünceleri ve gerçek sonuç arasındaki fark hissettirilebilir. Bu anlamda kurulacak değişik 
devre düzenekleri ile voltmetreleri kullanarak ölçüm yapmaları ve ölçümden önce tahminleri istenerek ölçüm sonucu ile karşılaştırmaları sağlanmalıdır. Bu

\section{Kaynaklar}

[1] Duit, R. Vorste11ung und Physiklernen. Physik in der Schule, 30, 282-285, (1992).

[2] Hoffman, L., Naturwissenschaftlich-techische Bildung undberufliche Orientierung (Teil A), in W. Lenkse, (Ed.). Frauen im Beruf. Förderung naturwissenschaftlich- technischer Bildung /Ür Miidchen in der Realschule, 118148 (1990).

[3] Duit, R. ve Rhöneck, C. Learning and understanding key concepts of elektricity, (1997). http://www.physics.ohiostate.edu/jossemlICPElC2MC.htlm, (15.03.2004).

[4] Günbatar, S. ve Sarı, M., Elektrik ve manyetizma konularında anlaşılması zor kavramlar için model geliştirilmesi, Gazi Eğitim Fakültesi Dergisi, 25, 1, 185-197, (2005).

[5] Örgün, E., Lise öğrencilerinin elektrik akımı konusundaki kavram yanılgılarında yapıcı öğretim yaklaşımının etkisi, Yüksek Lisans Tezi, Marmara Üniversitesi, Eğitim Bilimleri Enstitüsü, İstanbul, (2002).

[6] Küçüközer H., Yapılandırmacı öğrenme kuramına dayalı olarak geliştirilen öğretim modelinin lise 1. Sınıf öğrencilerinin basit elektrik devrelerine ilişkin kavramsal anlamalarına etkisi, Doktora Tezi, Balıkesir Üniversitesi, Fen Bilimleri Enstitüsü, Balıkesir. (2004).

[7] Ates, S,. The effectiveness of the learningcycle method on teaching DC circuits to prospective female and male science teachers. Research in Science \& Technological Education, 23, 2, 213-227, (2005).

[8] Ateş, S. ve Polat M., Elektrik devreleri konusundaki kavram yanılgılarının giderilmesinde öğrenme evreleri metodunun etkisi. Hacettepe Üniversitesi Eğitim Fakültesi Dergisi, 28, 39-47, (2005).

[9] Gönen, S., Kocakaya, S. ve İnan, S., The effect of the computer assigted teaching and $7 \mathrm{E}$ model of the constructivist learning methods on the achievements and attitudes of high school students. Turkish Online Journal of Educational Technology, 5, 4, 1303-6521, (2006).

[10] Yılmaz, H. ve Huyugüzel Çavaş, P., 4-E öğrenme halkası yönteminin öğrencilerin elektrik konusunu anlamalarına olan etkisi, Türk Fen Eğitimi Dergisi, 3, 1, 1-18, (2006). yöntemle öğrencilerin kavram yanılgıları bilimsel gerçeklere doğru ikna edici bir şekilde değiştirilebilir.

[11] Yılmaz, G.K., Ertem, E. ve Çepni, S., The effect of the material based on the 7E model on the fourth grade students' comprehension skill about fraction concepts, Procedia Social and Behavioral Sciences, 2, 1405-1409, (2010).

[12] Eryılmaz A., ve Sürmeli E. Üç aşamalı sorularla öğrencilerin 1 sı ve sicaklık konularındaki kavram yanılgılarının ölçülmesi. V. Ulusal Fen Bilimleri ve Matematik Eğitimi Kongresi (2002).

[13] Stepans, J. Targeting Students' Science Misconceptions: Physical Science Concepts Using the Conceptual Change Model. Riverview, Fla.: Idea Factory, (1996).

[14] Yıldırım H. İ., Yalçın N., Şensoy Ö. ve Akçay S., İlköğretim 6., 7. ve 8. sınıf öğrencilerinin elektrik akımı konusunda sahip oldukları kavram yanılgıları, Kastamonu Eğitim Dergisi, 16, 1, 67-82, (2008).

[15] Küçüközer, H., Lise öğrencilerinin basit elektrik devreleri konusuyla ilgili kavram yanılgısı. Hacettepe Üniversitesi Eğitim Fakültesi Dergisi, 25, 142-148, (2003).

[16] Karakuyu Y. ve Tüysüz C., Elektrik konusunda kavram yanılgıları ve kavramsal değişim yaklaşımı, Gaziantep Üniversitesi Sosyal Bilimler Dergisi, 10, 2, 867-890, (2011).

[17] Altun S., Üç aşamalı bir testle fen bilgisi öğretmen adaylarının basit elektrik devreleri konusundaki kavram yanılgılarının tespiti. Bayburt Üniversitesi Eğitim Fakültesi Dergisi, 4, 1-2, (2009).

[18] Engelhardt, P. V., ve Beichner, R. J., Students' understanding of direct current resistive electrical circuits. American Journal of Physics, 72, 98-115, (2004).

[19] Salar, R., Öğretmen adaylarının elektrik devreleri ile ilgili kavram yapılarının repertuvar çizelge ve kavram haritasıyla belirlenmesi, Yüksek Lisans Tezi, Gazi Üniversitesi, Eğitim Bilimleri Enstitüsü, Ankara, (2011).

[20] Bar, V. ve Travis, A., Children's views concerning phase changes. Journal of Research in Science Teaching, 28, 4, 363382, (1991).

[21] Şahin , Ç. ve Çepni, S., Yüzme-batma, kaldırma kuvveti ve basınç kavramları ile ilgili iki aşamalı kavramsal yapılardaki farklılaşmayı belirleme testi geliştirilmesi, Türk Fen Eğitim Dergisi, 8, 1, 79-109, (2011). 
[22] Shipstone, D.M.. Rhöneck, C.V., Karrqvist, C., Dupin, J., Johsua, S. ve Licht, P., A study of students' understanding of electricity in five European countries, International Journal of Science Education, 10, 3, 303316, (1988).

[23] Çıldır, I., ve Şen, A.İ., Lise öğrencilerinin elektrik akımı konusundaki kavram yanılgilarının kavram haritalarıla belirlenmesi, Hacettepe Üniversitesi Eğitim Fakültesi Dergisi, 30, 92-101, (2006).
[24] Toraman, S., ve Alcı, B., Fen ve teknoloji öğretmenlerinin yenilenen fen bilimleri dersi öğretim programına ilişkin görüşleri, Ekev Akademi Dergisi, 17, 56, (2013).

[25] Tunç, T., Akçam, H.K. ve Dökme, İ., Sınıf öğretmeni adaylarının bazı fizik konularındaki kavram yanılgıları ve araştırmada uygulanan tekniğin araştırma sonucuna etkisi, Türk Fen Eğitimi Dergisi, 9, 3, 137-153, (2012). 